\title{
EQUALITY-ORIENTED HORIZONTAL POLICIES IN SOUTH AFRICAN PUBLIC PROCUREMENT
}

\author{
Christian Helmrich
}

\section{(2014) 1 APPLJ 61}

\begin{abstract}
In the ever-present fight against poverty, governments are in constant need of effective and efficient policy instruments. Typically, poverty is addressed by tax-based systems of social grants. However, due to financial constraints, instruments that seek to involve the private sector gain more and more attention. Creating such synergies is particularly important for developing countries.

In this context, South Africa has implemented and further developed a system of preferential procurement. While the 'traditional' focus of public procurement is 'value for money', procurement policies increasingly pursue other goals, such as social or environmental ones. In South Africa, one of the award criteria is the tenderer's B-BBEE status. In doing so, public procurement in South Africa also aims at redressing past inequalities. Moreover, it is perceived as a valuable instrument in the fight against poverty.

This article tries to develop an analytical framework in which the effectiveness and efficiency of the South African system of preferential procurement can be assessed. The argumentation builds on two hypotheses: First, the South African system of preferential procurement pursues two different goals: the promotion of equality and the alleviation of poverty. Second, preferential procurement is ineffective with regards to both these goals.

Thus the focus lies not on the viability of horizontal policies in general but on horizontal policies for particular purposes. Furthermore, the article takes into account both the economic perspective as well as the normative perspective. There are several factors that cause doubts whether preferential procurement in South Africa effectively addresses poverty issues. Consequently, if we are to justify preferential procurement, we need to adopt a normative view and focus on the concept of substantive equality. Unlike social grants, preferential procurement is capable of promoting the participative dimension of equality - an important aspect of the transformational process in South Africa.
\end{abstract}




\title{
EQUALITY-ORIENTED HORIZONTAL POLICIES IN SOUTH AFRICAN PUBLIC PROCUREMENT
}

\author{
Christian Helmrich ${ }^{*}$ \\ Dr. jur., Ass. Jur., LL.M.
}

Scientific assistant, University of Regensburg

\section{Introduction}

The state ${ }^{1}$ is an important actor in most countries' economy. In both developed ${ }^{2}$ and developing ${ }^{3}$ countries public procurement, i.e. the acquisition of goods and services by public authorities from private actors, ${ }^{4}$ plays a significant role. Through the sheer quantity of expenditure $^{5}$ the state holds significant economic power. ${ }^{6}$ From here the step to using procurement not only as a means to acquire needed goods or services but also as a means to promote certain policy objectives is not far. The economic power gained from spending large amounts of money could be used as a tool to implement other values, most importantly environmental and social ones. Thus public procurement law commonly is not only seen as a tool to purely regulate the buying process, but also as a general policy instrument. ${ }^{7}$ Such policies are referred to as "horizontal policies" ${ }^{8}$ When discussing

\footnotetext{
* I would like to thank Prof Geo Quinot and Prof Alexander Graser for very valuable comments. This article was written while being a student at the Faculty of Law at Stellenbosch University, South Africa.

${ }^{1}$ The article will focus only on public procurement. It however has to be noted that in South Africa, by means of the B-BBEE Act, private procurement is also influenced by similar policy objectives, Bolton \& Quinot 2011:460.

${ }^{2}$ On average, developed countries spend about $45 \%$ of their Gross Domestic Product (GDP), Brammer \& Walker 2007:3.

34.

${ }^{4}$ Bolton 2007:1, 3. The definition given by Bolton admittedly is more complicated than that but for the purpose of this text the simplified version should be sufficient. It however is to be mentioned that the term "procurement" is not restricted to public actors and that, at least in the South African context, procurement, besides acquisition, can also mean sale of goods; Bolton 2007:3. On the purchasing part also see Furneaux \& Barraket 2014:266. On a more elaborate description of public procurement see Ambe \& Badenhorst-Weiss 2012:244.

${ }^{5}$ South Africa's GDP amounted to about $\$ 350.6$ billion in 2013, World Bank, 2013. South Africa. [online] Available at: <http://data.worldbank.org/country/south-africa> [Accessed: 23 March 2015]. Even if South Africa probably does not reach the $45 \%$ average of developed countries, the amount spent on procurement still is significant.

${ }^{6}$ Bolton 2006:193.

${ }^{7}$ Fuchs 2012:289; Brammer \& Walker 2007:4 et seq.; Bolton 2006:193; Semple 2012:2.

${ }^{8}$ Arrowsmith 2010:149; more detailed below 22.
} 
horizontal policies in public procurement, the respective context is crucial. ${ }^{9}$ The focus of this text is South Africa and this, as will be shown, entails some aspects rather unique to the South African context.

\section{Preferential Procurement in South Africa}

In South Africa public procurement is, among other purposes, used "as a policy tool due to the discriminatory and unfair practices during apartheid". ${ }^{10}$ The apartheid years saw the state contracting with large companies which were usually owned by whites. ${ }^{11}$ In order to address this discriminatory practice, contracts are now awarded, within certain boundaries, ${ }^{12}$ preferably to historically disadvantaged persons, ${ }^{13}$ thus the term preferential procurement.

\section{Research question}

While this use of preferential procurement appears to be largely accepted in South Africa, ${ }^{14}$ the concept is worth a closer look. The general direction, i.e. reducing discrimination caused by apartheid, is common cause. However, often the exact purpose of preferential procurement remains unclear and, arguably even more importantly, it is uncertain which exact outcome is desired. Discussions on the use of horizontal policies in public procurement in general are common in legal, economic and sociological literature. Horizontal policies however are only rarely assessed with regard to particular purposes. This paper seeks to address that issue. With regard to the preferential procurement policy in South Africa, it will start with two propositions:

(1) Preferential procurement in South Africa seeks to pursue two distinctively different goals. The first goal is the promotion of equality by addressing

\footnotetext{
${ }^{9}$ McCrudden 2009:126.

${ }^{10}$ Ambe \& Badenhorst-Weiss 2012:242.

${ }^{11}$ Bolton 2008:785.

12 An example for such boundaries and the relevance of belonging to a designated group within the procurement context is Cash Paymaster Services (Pty) Ltd vs The Province of the Eastern Cape [1997] 4 All SA 363 (Ck) where the court "stressed the importance of the attainment of value for money", Bolton 2008:794; Mokakala 2010:34-35.

${ }^{13} \mathrm{~S} 2$ (1) of the PPPFA. It has to be noted that the 2011 regulations only refer to the B-BBEE status of suppliers.

${ }^{14}$ On this see 32 .
} 
inequalities resulting from apartheid. The second goal is the alleviation of poverty.

(2) Understood this way, preferential procurement is, due to systemic flaws, ineffective in pursuing the goal of poverty-alleviation. Furthermore, it also struggles to promote equality.

This way, the focus is not horizontal policies in general, but horizontal policies for particular purposes, i.e. the alleviation of poverty and promotion of equality. The effectiveness and efficiency of the current South African approach will be examined.

\section{Structure, scope and research methodology}

The first step in order to examine the propositions mentioned above will be to look at the purposes of procurement law and the role of general policy objectives in this context. Building on this, general criticism on such horizontal policies will be described. In order to do so, it is sensible to look at the European Union law, a system of procurement law which is traditionally cautious when it comes to horizontal policies. This cautious European approach will be contrasted with the general acceptance of horizontal procurement, especially those dealing with apartheid-caused inequalities, in South African law.

Building on this foundation, the text will then address the distinction of different goals as mentioned in the first proposition, i.e. reducing inequalities caused by apartheid and alleviating poverty. Especially this second goal is not obvious and worth a closer look. After having established what pursuing each of those goals really means, the text will seek to evaluate whether preferential procurement can be an effective tool to promote equality and to alleviate poverty in South Africa and thus try to comment on the second proposition.

Aside from a brief description of the South African legal context of preferential procurement, the focus will only be on more general thoughts on the principle of preferential procurement and not its detailed implementation. It however has to be noted that the implementation of the horizontal policy does affect the policy's impact. ${ }^{15}$ The approach adopted in this text is one that tries to formulate statements on the purposes of

${ }^{15}$ Quinot 2013:377. 
preferential procurement and their respective practical relevance. Given the general lack in empirical research on the impact of horizontal policies, ${ }^{16}$ a more detailed discussion of implementation methods would exceed the scope of this text.

\section{Purposes of public procurement law}

At first, it is necessary to describe the different purposes of procurement law. In this context it will then be possible to evaluate common criticism and objections against horizontal policies.

\section{1 'Traditional' purposes of procurement law}

Public procurement traditionally is regulated by a set of rules in order to promote costeffectiveness. In this regard, it could be argued that the goal of public procurement law is "best value for money"17 This traditional ${ }^{18}$ purpose is also reflected in the General Procurement Guidelines issued by the National Treasury of the Republic of South Africa which list "Value for Money" as the first pillar in the five-pillar-model of public procurement. $^{19}$

Closely related to this 'best value' approach is another traditional purpose of procurement law - to regulate competition among tenders..$^{20}$ In a free- or social-market economy it can be assumed that competition among tenders ultimately leads to a lower price for the purchased good as the tenders, in order to be awarded the contract, are interested in offering the needed goods for the cheapest possible price. The General Procurement Guidelines in South Africa thus list "Open and Effective Competition" as the second pillar of procurement. $^{21}$

\footnotetext{
${ }^{16}$ See on this 412.

${ }^{17}$ Mille 2006:489; Arrowsmith 2010:150 speaks of "obtaining goods [...] on the best terms".

18 In line with Arrowsmith I will avoid the term 'primary' as it implies an unjustified illegitimacy of, then 'secondary', horizontal policies, Arrowsmith 2010:150; slightly different Bolton 2006:193: "aims which are, arguably, secondary to the primary aim of procurement".

${ }^{19}$ National Treasury of the Republic of South Africa. General Procurement Guidelines. [online] Available at: <http://www.treasury.gov.za/legislation/pfma/supplychain/General\%20Procurement\%20Guidelines.pdf> [Accessed 13 January 2015]:3 et seq.

${ }^{20}$ Fuchs 2012:289.

${ }^{21}$ National Treasury. General Procurement Guidelines:5.
} 


\section{Horizontal policies}

However, the purposes of public procurement law do not end here. It has already been mentioned that public procurement commonly is used for a variety of policies. ${ }^{22}$ In South Africa, this use is explicitly promoted in section 217 (2) and (3) of the Constitution. ${ }^{23}$ According to these provisions, public procurement policy $\operatorname{can}^{24}$ contain "categories of preference in the allocation of contracts" 25 as well as "[protect or advance] persons, or categories of persons, disadvantaged by unfair discrimination" ${ }^{26}$. Section 217 (3) of the Constitution then requires the state to take legislative measures in order to promote these goals. These measures are contained in the Preferential Procurement Policy Framework Act. $^{27}$

Such policies go beyond ensuring the acquisition of goods "on the best terms". ${ }^{28}$ Regarding only the acquired goods and comparing them to their price, the state has no advantage in buying from persons who have been discriminated against during apartheid. Neither are the goods necessarily cheaper nor necessarily of better quality. Thus such policy as contained in section 217 (2) of the Constitution and the PPPFA cannot be justified by traditional purposes of public procurement law.

\section{Policies linked to the contract}

Especially in European Union law the requirement of a link between the policy and the "subject-matter of the contract" ${ }^{29}$ has been well established as a requirement for the validity of horizontal policies. ${ }^{30}$ This is understandable when the purpose of procurement law to regulate competition among tenders ${ }^{31}$ is taken into account. Equal competition which

\footnotetext{
${ }^{22}$ Arrowsmith 2010:149; examples for policies that go beyond pure cost-effectiveness are rules that order a contracting company to adhere to certain labour standards, 153, or environmental standards, Lukosiuniene \& Lukosiunas 2014:175.

${ }^{23}$ Constitution of the Republic of South Africa, 1996, ("the Constitution"); Anthony 2013:28; Bolton 2007:252, 263; Bolton \& Quinot 2011:461.

${ }^{24}$ But does not have to, Bolton 2007:264.

${ }^{25} \mathrm{~S} 217$ (2) (a).

${ }^{26} \mathrm{~S} 217$ (2) (b).

${ }^{27}$ Act 5 of 2000; Bolton \& Quinot 2011:461.

${ }^{28}$ Arrowsmith 2010:150; Bolton \& Quinot 2011:459.

${ }^{29}$ ECJ C-513/99 [2002] ECR I-07213 Concordia at para 59; Semple 2012:14.

${ }^{30}$ Semple 2012:14

${ }^{31}$ See 21.
} 
ultimately should ensure the best possible price for the goods needed by the state ${ }^{32}$ would be distorted by horizontal policies which are in no way linked to the contract and the purchased good. $^{33}$

There has been and still is uncertainty on the requirements of a sufficient link between policy and contract. This issue will be addressed again in the context of horizontal policies in European Union law. ${ }^{34}$ For now it is sufficient to recognize that there are policies that are linked to the content of the contract and that they, at least in European Union law, can be justified more easily in the system of public procurement law.

\section{Policies with no or only a remote link to the contract}

Policies which are not sufficiently linked to the contract pose more challenges to their justification in the procurement system. They can distort competition between tenderers and thus potentially be more detrimental to traditional purposes of procurement law than horizontal policies which have a close link to the contract and the purchased goods.

Arrowsmith speaks of three "key distinctions" of horizontal policies. ${ }^{35}$ The issue of a sufficient connection to the contract is reflected in her second distinction, i.e. "policies concerned only with performance of the contract". ${ }^{36}$ With regard to preferential procurement in South Africa based on grounds of race there will hardly be a link to the contents of the contract. The fact whether a tenderer belongs to a historically disadvantaged group of persons or not has no connection to the contents of the procurement contract. In this context another aspect is relevant: In addition to Arrowsmith's three distinctions a fourth one can be made. Policies which connect the award of a contract to requirements that can be influenced by the tenderer and policies that use criteria which cannot be influenced by the tenderer. There is a difference in legitimacy between having a tenderer obey certain labour standards such as minimum wages and preferentially awarding contracts on grounds of race or gender. The tenderer can influence

\footnotetext{
${ }^{32}$ See 21.

${ }^{33}$ Hjelmborg et al 2006:218.

${ }^{34}$ See 31.

${ }^{35}$ Arrowsmith 2010:151.

${ }^{36} 151$; the other two distinctions being compliance with legal obligations or beyond and different mechanisms of implementation, 151.
} 
the first criterion but he cannot influence the latter. That certainly does not imply that preferences based on race or gender are always illegitimate, but there is an additional obstacle of legitimacy that has to be overcome. ${ }^{37}$

\section{Horizontal policies in European Union law and South African law}

Horizontal policies in public procurement have often been criticised. McCrudden identifies seven categories of objections: ${ }^{38}$ Contracts are not the place for policies in the public interest, $^{39}$ promoting certain (social) outcomes through procurement is costly, ${ }^{40}$ the preference for certain persons or certain groups of persons is unfair and discriminatory, ${ }^{41}$ linkages are not needed as the state can regulate directly, ${ }^{42}$ horizontal policies are detrimental to traditional purposes of procurement law, ${ }^{43}$ procurement law becomes too bureaucratic $^{44}$ and horizontal policies can shift powers which should belong to the legislature to the executive. ${ }^{45}$

Some of these aspects appear more valid than others. Taking into account public interests in contracts for example is not an uncommon phenomenon even in contracts concluded between two private persons. ${ }^{46}$ While this often will have to be justified, the mere fact that a horizontal policy in public procurement uses contractual relationships is not a valid argument against horizontal policies per se; especially since one of the parties to the contract is the state. Also the argument that horizontal policies are costly is not necessarily convincing as the state ideally gains positive effects on matters of public interest ${ }^{47}$ which it had to regulate anyway. ${ }^{48}$

\footnotetext{
${ }^{37}$ This obstacle arguably is reflected in criticism on affirmative action in general. Whether such criticism is justified or not has to be evaluated. This however will not be the topic for this text.

${ }^{38}$ McCrudden 2007:114 et seq.

39115 .

${ }^{40} 115$ et seq.

${ }^{41} 118$.

42 118-119.

$43119-120$.

$44120-121$.

45 121-122.

${ }^{46}$ On the situation in German law see for example Westermann 2008.

${ }^{47}$ Letchmiah 2012:292.

${ }^{48}$ On this see 54.
} 
One of the more convincing aspects of criticism is that horizontal policies can be detrimental to traditional purposes of procurement law. In order to ensure cost-effectiveness and 'best value for money', procurement law needs a formal, rigid and transparent regulatory mechanism, which is softened by criteria such as preference because of race. ${ }^{49}$ This argument is closely linked to the more general argument of horizontal policies being costly. The softer procurement regulations get, the more the goal of cost-effectiveness is endangered. While the state will indeed gain something in exchange for the additional costs, i.e. positive effects on matters of public interest, the comparison with traditional purposes of procurement law raises the question whether procurement law is the correct field to pursue such policies.

With regard to preferential procurement in South Africa the argument that horizontal policies can be discriminatory to certain groups obviously is relevant and thus has to be addressed. However, considering that preferential procurement is a form of affirmative action, the argument brought forward with regard to horizontal policies does not seem to add many new aspects to the discussion already revolving around affirmative action measures. It therefore will be referred to the existing criticism. ${ }^{50}$

\section{European Union law}

As one of the main fields of public procurement law, the position in European Union law is worth a look. It is to be evaluated what can be taken from the general position on horizontal policies in European procurement law.

In line with the history of the European Union as a free-market instrument and a general hesitation of European Union law with regard to social matters, social policies in public procurement were dealt with only in recent years. ${ }^{51}$ This also meant that the approach to horizontal policies in procurement law in the European Union traditionally was rather restrictive. The focus of procurement law was, in line with the traditional view of

\footnotetext{
${ }^{49}$ Similarly Hjelmborg et al 2006:213.

${ }^{50}$ See 51.

${ }^{51}$ Lukosiuniene \& Lukosiunas 2014:174. Arguably this is part of a general shift in European Union law from a purely market-oriented union to one more concerned with other values such as social and environmental ones. The perhaps most apparent step in this recent process was the recognition of the European Charter of Fundamental Rights as binding EU law through the treaty of Lisbon.
} 
procurement law as described above, to organize competition amongst private actors and thus ensure a cost-effective acquisition of goods by public actors. ${ }^{52}$ In doing so, procurement law was mainly seen as a regulatory instrument for the acquisition of goods, i.e. the buying process, not as regulation of other purposes such as environmental and social ones. $^{53}$

However, horizontal policies are not a complete stranger to European procurement law. The European Court of Justice (ECJ) stated that award criteria in procurement law can contain social and environmental objectives, i.e. horizontal policies, as long as these goals show a connection to the contract. ${ }^{54}$ This imposed rather strict boundaries on horizontal policies and the ECJ in Concordia expressly stated that the state's choice in procurement may "relate only to criteria aimed at identifying the economically most advantageous tender." ${ }^{55}$ This clearly shows that the focus in European Procurement law used to be 'value for money'.

The approach arguably has shifted when reforms of European procurement law started in 2011 and for now culminated in directive 2014/24/EU of 26 February 2014. ${ }^{56}$ Especially recital 36 of the directive ${ }^{57}$ contains a clear sign for a more accepting approach towards horizontal policies in public procurement. ${ }^{58}$

\section{Social policies in South African public procurement law}

Horizontal policies are important in South African public procurement law. ${ }^{59}$ They root in section 217 of the Constitution and in the Preferential Procurement Policy Framework Act. ${ }^{60}$ It has been mentioned that horizontal policies in procurement can - and do - promote all

\footnotetext{
${ }^{52}$ Fuchs 2012:289; Lukosiuniene \& Lukosiunas 2014:178.

${ }^{53}$ Fuchs 2012:289.

${ }^{54}$ Mille 2006:489.

${ }^{55}$ ECJ C-513/99 [2002] ECR I-07213 Concordia at para 59; Semple 2012:14.

${ }^{56}$ Lukosiuniene \& Lukosiunas 2014:174 et seq., also see Fuchs 2012:289.

${ }^{57}$ Recital 36 reads in excerpt:

"it is appropriate to provide that Member States should be able to reserve the right to participate in award procedures for public contracts or for certain lots thereof to such workshops or businesses [whose main aim is to support the social and professional integration or reintegration of disabled or disadvantaged persons, such as the unemployed, members of disadvantaged minorities or otherwise socially marginalised groups,] or reserve performance of contracts to the context of sheltered employment programmes."

58 "EU public procurement gradually developed to the point where social matters are being tackled more than ever", Lukosiuniene \& Lukosiunas 2014:180.

59 Bolton 2006:193-194.

${ }^{60}$ Act 5 of 2000 .
} 
sorts of goals, e.g. various social or environmental objectives. ${ }^{61}$ In the South African context, due to the apartheid history, ${ }^{62}$ race-based social procurement is of particular importance.

\section{Section 217 of the South African Constitution}

In South Africa preferential procurement based on race appears to be widely accepted, one of the reasons being South Africa's apartheid history. ${ }^{63}$ Unlike most other constitutions, ${ }^{64}$ the South African Constitution contains a section particularly on procurement. ${ }^{65}$ The constitutional provision binds "organs of state" ${ }^{66}$ when concluding contracts in their own interest as well as on behalf of the public. ${ }^{67}$ In the Namibian Constitution there are provisions that can possibly make the use of public social procurement mandatory, e.g. to fight poverty. ${ }^{68}$ Unlike these provisions, the South African Constitution only contains an "explicit mandate for the use of public procurement for social policy purposes", 69 it does not require parliament to do so. ${ }^{70}$ It however should be noted that - given the explicit acknowledgment in the Constitution - preferential procurement in South Africa stands on relatively solid legal ground. ${ }^{71}$ The Constitution now also requires criteria other than price in the procurement process. $^{72}$

\footnotetext{
${ }^{61}$ See for example Watermeyer 2003:11-12.

62 Bolton 2006:193.

${ }^{63}$ Brammer \& Walker 2007:14.

${ }^{64}$ Bolton 2008:782: "unique".

${ }^{65}$ S 217 reads "Procurement
}

217. (1) When an organ of state in the national, provincial or local sphere of government, or any other institution identified in national legislation, contracts for goods or services, it must do so in accordance with a system which is fair, equitable, transparent, competitive and cost-effective.

(2) Subsection (1) does not prevent the organs of state or institutions referred to in that subsection from implementing a procurement policy providing for -

(a) categories of preference in the allocation of contracts; and

(b) the protection or advancement of persons or categories of persons, disadvantaged by unfair discrimination.

(3) National legislation must prescribe a framework within which the policy referred to in subsection (2) may be implemented."

${ }^{66} \mathrm{~S} 217$ (1).

${ }^{67}$ Bolton 2008:786.

${ }^{68}$ Quinot 2013:373-374.

69374.

${ }^{70}$ Bolton 2007:264; Penfold \& Reyburn 2014:25-13. In this regard it is referred to the policy being "an interim" measure, Anthony 2013:59, Bolton 2007:264. This is a common approach to such policies, Sweet 2006:171, which seek to create spillover effects and "foster long-term changes in behaviour that will eventually obviate the need for the government programme", 171.

${ }^{71}$ This solid ground has to be taken into account when criticising the system of preferential procurement in South Africa, particularly when raising the question whether the policy is viable at all.

72 Penfold \& Reyburn 2014:25-1. 


\section{Preferential Procurement Policy Framework Act (PPPFA)}

The PPPFA was enacted to give effect to section 217 (3) of the Constitution. ${ }^{73}$ It applies to "organs of state as contemplated in section 1 (iii) of the Act". ${ }^{74}$ This includes national and provincial departments per definition in the Public Finance Management Act, ${ }^{75}$ municipality as referred to in the Constitution, constitutional institutions which are defined in the Public Finance Management Act, parliament, provincial legislatures and institutions encompassed by the term "organ of state" in section 239 of the Constitution and recognized by the Minister. ${ }^{76}$

After Black Economic Empowerment (BEE) was substituted by Broad-Based Black Economic Empowerment (B-BBEE), the need for updated procurement regulations arose. ${ }^{77}$ The new preferential procurement regulations thus were adopted in $2011 .^{78}$ Aside from other - more technical - changes, ${ }^{79}$ the most important change in the present context is constituted by a change in target group. ${ }^{80}$ By means of the 2011 procurement regulations the references to "historically disadvantaged individuals" and the Reconstruction Development Programme were substituted by a reference to B-BBEE goals. ${ }^{81}$ The criterion for preferential procurement now is the B-BBEE status level of a tenderer. ${ }^{82}$ Depending on the value of the contract, up to $10^{83}$ or up to $20^{84}$ points can be awarded to tenderers based on their B-BBEE status.

\footnotetext{
${ }^{73}$ Bolton 2008:783, 786. Bolton lists further legislation enacted to give effect to the constitutional provisions, namely the Public Finance Management Act (1 of 1999, amended 29 of 1999), the Municipal Finance Management Act (56 of 2003), the Municipal Systems Act (32 of 2000, amended 44 of 2003), the Prevention and Combating of Corrupt Activities Act (12 of 2004) and National Treasury guidelines, 783.

${ }^{74}$ S 2 (1) of the Preferential Procurement Regulations 2001.

${ }^{75}$ Act 1 of 1999.

${ }^{76} \mathrm{~S} 1$ (iii) of the PPPFA. It must also be noted that $\mathrm{s} 3$ of the PPPFA contains the possibility of an exemption on request because of national security, the likely tenderers being international or public interest.

${ }^{77}$ Quinot 2013:394; McCrudden 2009:140.

${ }^{78}$ Quinot 2013:394; Bolton 2011:7.

${ }^{79}$ Such as changes concerning the value of the contract for application of the $80 / 20$ or $90 / 10$ system, coverage of the regulations, changes concerning sale and letting as well as changes concerning fraud in the tendering process, Anthony 2013:62-63 with a comprehensive overview. See also Bolton 2011:7.

${ }^{80}$ Quinot 2013:402.

${ }^{81}$ McCrudden 2009:140.

${ }^{82}$ Ss 5 (2), (3), 6 (2), (3) of the 2011 Regulations; Anthony 2013:62. S 1 (d) of the 2011 Regulations defines the B-BBEE status level as "the B-BBEE status received by a measured entity based on its overall performance using the relevant scorecard contained in the Codes of Good Practice on Black Economic Empowerment, issued in terms of section 9 (1) of the Broad-Based Black Economic Empowerment Act", 62 n 219.

${ }^{83}$ For contracts with a value above 1 Million Rand, s 5 of the 2011 Procurement Regulations.
} 


\begin{tabular}{|c|c|}
\hline B-BBEE Status Level of Contributor & Number of Points \\
\hline 1 & 20 \\
\hline 2 & 18 \\
\hline 3 & 16 \\
\hline 4 & 12 \\
\hline 5 & 8 \\
\hline 6 & 6 \\
\hline 7 & 4 \\
\hline 8 & 2 \\
\hline Non-compliant contributor & 0 \\
\hline
\end{tabular}

2011 Procurement Regulations sec 5 (2), 80/20 preference point system

\begin{tabular}{|c|c|}
\hline B-BBEE Status Level of Contributor & Number of Points \\
\hline 1 & 10 \\
\hline 2 & 9 \\
\hline 3 & 8 \\
\hline 4 & 5 \\
\hline 5 & 4 \\
\hline 6 & 3 \\
\hline 7 & 2 \\
\hline 8 & 1 \\
\hline Non-compliant contributor & 0 \\
\hline
\end{tabular}

2011 Procurement Regulations sec 6 (2), 90/10 preference point system

The idea underlying this change is to combat fronting, corruption and fraud ${ }^{85}$ by removing any discretion previously awarded to authorities in terms of the preference point system. ${ }^{86}$ Being historically disadvantaged is therefore no longer a criterion for preferential treatment; ${ }^{87}$ two of the criteria for the B-BBEE status however are "ownership" and "management control". ${ }^{88}$ The purpose of addressing past unfair discrimination is still apparent. $^{89}$

\section{Open questions}

Despite this wide acceptance in South Africa there still appear to remain unanswered questions. Considering the constitutional provisions, these questions cannot revolve around whether South Africa can use procurement regulation as a social policy instrument. This question has been answered by s 217 (2) of the Constitution. In this regard the problems in

\footnotetext{
${ }^{84}$ For contracts with a value up to 1 Million Rand, s 6 of the 2011 Procurement Regulations.

${ }^{85}$ Letchmiah 2012:308.

${ }^{86}$ Quinot 2013:398.

87399.

88399.

${ }^{89} 401$ for southern African systems in general.
} 
South Africa differ from those under European Union law. The unanswered questions revolve around whether South Africa should use preferential procurement to reduce apartheid-caused inequalities and to alleviate poverty. Section 217 (2) of the Constitution, in not making preferential procurement mandatory, is largely silent on this issue.

\section{Conclusion}

Especially considering the evolution in modern European Union procurement law, it can be stated that the principle of horizontal policies in procurement has gained significant support and should be seen as accepted in European Union law, ${ }^{90}$ a system which traditionally has been hesitant with regard to social policies. ${ }^{91}$ In this light, general criticism on horizontal policies and a retreat to 'pure' procurement law focusing only on 'best value for money' does not seem to further the understanding of either procurement law or social law. ${ }^{92}$ Thus the focus of the discussion should not be whether horizontal policies in procurement are viable at all, but rather to what extent, under which circumstances and for which goals. This leads to one of the main issues of this paper: The acceptance of the general principle does not necessarily imply the acceptance of a particular type of horizontal policy. Each policy has to be looked at individually and examined with regard to its viability in the procurement law context.

\section{Goals of "horizontal policies"93 in South Africa}

Criticism on horizontal policies in procurement can roughly be divided into two categories: firstly, the policy is ineffective in achieving the desired outcome, i.e. the result is not good enough. ${ }^{94}$ Secondly, the policy is inefficient in achieving the desired outcome, i.e. it may reach its targets, but the costs are too high. ${ }^{95}$

\footnotetext{
90 Lukosiuniene \& Lukosiunas 2014:180 expect even further acceptance for social an environmental values in EU procurement law in the future.

${ }^{91}$ The exact boundaries of horizontal policies in European law however still need to be evaluated. This is especially relevant for the issue of a sufficient link to the subject-matter of the contract.

92 On that matter it seems worth noting that, at least in a comparative perspective, social policies in public procurement law form a type of social law; on the definition of social law in the comparative context Zacher 2008.

${ }^{93}$ Arrowsmith 2010:149.

${ }^{94}$ Descriptive see Watermeyer 2000:230.

${ }^{95}$ On the issue of costs related to horizontal policies see Watermeyer 2003:13 and below 54.
} 
A lot has been written about horizontal policies in public procurement especially in the South African context. ${ }^{96}$ Within the EU horizontal policies traditionally have been regarded with caution, acceptance however is rising. In South Africa, promoting social objectives through public procurement appears to be less controversial. Possible reasons for this include the deep inequalities resulting from the apartheid years ${ }^{97}$ and limited tax-based possibilities due to large unemployment rates. ${ }^{98}$

The first step in assessing preferential procurement policies necessarily has to be a clear description of the objectives that should be achieved by social horizontal policies. If the effectiveness and efficiency of social policies in public procurement are to be evaluated, a common framework needs to be reached. This includes a description of potential objectives as precisely as possible. It has to be noted that such a description and separation of goals is often hard to reach as goals are intertwined and often co-dependent.

The two goals most prominent in the discussion, and the sole focus of this paper, are the promotion of equality and the alleviation of poverty. While both issues are often, albeit not necessarily, related, ${ }^{99}$ it is important to distinguish. The reason for this is the character of affirmative action measures in general. Katiyatiya concludes that affirmative action measures in general are not "originally designed specifically to benefit the poor" ${ }^{100}$ and that "affirmative action has limited utility, and that it is by no means the principal mechanism through which wealth is redistributed or poverty reduced". ${ }^{101}$ This characterization of affirmative action measures cannot be overstated. It is furthermore backed by section 9 of the Constitution which lists affirmative action measures under the headline "Equality". ${ }^{102}$ The Constitution provides that in order "[t]o promote the achievement of equality, legislative and other measures designed to protect or advance persons, or categories of persons, disadvantaged by unfair discrimination may be taken". ${ }^{103}$

\footnotetext{
${ }^{96}$ See for example Quinot 2013; Bolton 2006; Bolton 2007:251 et seq.

${ }^{97}$ See de la Harpe 2009:499, 505.

98 De la Harpe for example states that in general, developing countries will more often rely on horizontal policies to achieve social objectives than developed countries, 499.

${ }^{99}$ For a general discussion of this relationship see van der Berg 2011:121 et seq.

${ }^{100}$ Katiyatiya 2014:236.

101236.

${ }^{102} \mathrm{~S} 9$ (2) of the Constitution.

${ }^{103} \mathrm{~S} 9$ (2) of the Constitution.
} 
A similar characterization is provided by section 217 (2) of the Constitution ${ }^{104}$ which states that "organs of state or institutions [...] [may implement] a procurement policy providing for [...] (b) the protection or advancement of persons, or categories of persons, disadvantaged by unfair discrimination". ${ }^{105}$ All of these constitutional provisions are in line with the introductory statement that affirmative action in general and preferential procurement in particular, aim at protecting and advancing persons who have been unfairly discriminated against. Preferential procurement thus aims at promoting equality. It does so by remedying inequalities caused by the apartheid regime. ${ }^{106}$

\section{Poverty-alleviation}

The PPPFA, however, in fulfilling section 217 (3) of the Constitution ${ }^{107}$ acknowledges in its section 2 (1) (d) as legitimate specific goals for preferential treatment in procurement not only "contracting with persons, or categories of persons, historically disadvantaged by unfair discrimination on the basis of race, gender or disability" 108 but also "implementing the programmes of the Reconstruction and Development Programme as published in Government Gazette No. 16085 dated 23 November 1994". ${ }^{109}$ The Reconstruction and Development Programme refers to the alleviation of poverty. ${ }^{110}$ Literature in large extent adopted this view. Besides the promotion or maintenance of equality, it has been submitted that preferential procurement can also provide an instrument to alleviate poverty. ${ }^{111}$ The

\footnotetext{
${ }^{104}$ Similarily Bolton 2007:263.

${ }^{105}$ S 217 (2) of the Constitution.

${ }^{106}$ Bolton 2007:264: "procurement as a means to address past discriminatory policies and practices".

107 "To give effect to section 217 (3) of the Constitution by providing a framework for the implementation of the procurement policy contemplated in section 217 (2) of the Constitution; and to provide for matters connected therewith", Preamble of the PPPFA; Bolton 2007:266.

${ }^{108} \mathrm{~S} 2$ (1) (d) (i).

${ }^{109}$ S 2 (1) (d) (ii). It however hast to be noted that the 2011 procurement regulations substituted references to the RDP by B-BBEE status, Bolton 2011:7. The framework contained in the PPPFA however remains the same. This difference between the regulations and the PPPFA may raise lawfulness questions, which fall beyond the scope of this paper.

${ }^{110}$ Bolton \& Quinot 2011:462 n. 17.

${ }^{111}$ See for example Sahle 2002:4; Watermeyer 2000:232; Basheka 2009:148 for the whole of Africa. This view arguably is contradictory to affirmative action as a tool to promote equality. It has to be admitted that the reference to the basic conceptualization of affirmative action measures can be misleading. Promoting poor groups of society (be it, as in South Africa, on the basis of race which often overlaps with poverty or on the basis of poverty and social standing itself. This refers to a lively discussion in South Africa on whether class or social status should be included in the listed grounds of s 9 of the Constitution. This discussion will not be specifically addressed in this text, reference will however be made where necessary) for example by means of improved opportunities particularly with regard to jobs and education can - plausibly - alleviate poverty, Katiyatiya 2014:209-210.
} 
relationship between preferential procurement, the promotion of equality and the alleviation of poverty however is complex and requires closer examination.

\section{Aspects of poverty}

When trying to assess the - potential - impact of preferential procurement on poverty, it is necessary to determine the content and understanding of poverty. It is no surprise that this definition is anything but straightforward. The concepts to describe poverty vary, according to Sen from a "capability-based approach" ${ }^{112}$ where poverty is seen as the incapability to "reach certain minimally acceptable levels", 113 to approaches which focus more on utility or low income. ${ }^{114}$ Poverty measurement, which looks solely on the income of persons, suffers from the flaw that persons may have different capabilities to transfer income into desired achievements because of for example "social, economic, or physical constraints as well as due to political interference". ${ }^{115}$ This is what Sen labels the "capability-based approach". 116

\section{Absolute or relative?}

The first important distinction is the one between the concepts of absolute and relative poverty. While there are several aspects in the measurement of poverty which can be labelled as absolute or relative, ${ }^{117}$ it can be summarized that an absolute approach defines poverty using a basket-model determining the amount of money needed to acquire a certain minimum of necessities. ${ }^{118}$ In contrast, a relative approach of poverty measurement defines the poverty line compared to the population's income, i.e. as a certain portion of for

It further has to be noted that poverty-alleviation of course is not the only, arguably not even the main objective of horizontal policies; see for example Bolton \& Quinot 2011:49 referring to "redress[ing] inequalities in the South African economy created by colonization and apartheid".

${ }^{112}$ Sen 1992:110.

${ }^{113} 109$. Sen points out that those levels vary from society to society and potentially include a range from the physical minimum such as sufficient nutrition to more society-based minima such as being part of the community, 110.

114110.

115 Fredman 2011:572; Sen 1992:110-111. Another illustrative example is the influence of location. Some locations for example require more spendings on security than others, 113.

${ }^{116}$ Sen 1992:110; Fredman 2011:572.

${ }^{117}$ Foster 1998:336.

${ }^{118}$ Madden 2000:182. It is to be noted that even absolute poverty lines are not cast in stone but, to a limited extent, can change over time, 182-183. An important example of an absolute poverty line is the official approach in the United States, Foster 1998:336. 
instance the median or average income. ${ }^{119}$ The distinction between absolute and relative poverty shows the link between poverty and inequality. ${ }^{120}$ The relative approach to measuring poverty is also more capable of grasping the problem of poverty in richer countries. The underlying understanding is that the richer a country is in general, the more money is (absolutely) needed to obtain the minimum necessities. ${ }^{121}$ This becomes especially apparent when it is accepted that poverty is not only the lack of basic physical needs but also has a social aspect. Adam Smith already acknowledged that poverty included psychological ${ }^{122}$ components, not only physical ones. ${ }^{123}$ One of these categories is the need to adapt to societal conventions ${ }^{124}$ which usually will be more expensive in a rich country than in a poor one. ${ }^{125}$ Poverty cannot be described without taking into account the social surroundings in which persons "necessarily exist". ${ }^{126}$ All this vastly extends the scope of poverty ${ }^{127}$ which in turn creates problems on its own. ${ }^{128}$ One of these problematic points is the relationship between equality and poverty. ${ }^{129}$

\footnotetext{
${ }^{119}$ Madden 2000:183; Foster 1998:336-337. Arguably the most important example for such an approach is the threshold of 50\% of the median income used by the OECD, Leibbrandt et al 2010:35.

${ }^{120}$ Sen 1992:9.

121 115; Sen 1983:161.

${ }^{122}$ Sen 1983:161 n 16.

${ }^{123}$ 161; Sen 1992:110: "taking part in the life of the community"; Fredman 2011:569, 573. The German Federal Constitutional Court (Bundesverfassungsgericht) has (at latest) in its 2010 landmark decision on the amount of welfare grants adopted a similar position. It especially acknowledged that the minimum living conditions as protected by the Constitution not only contained physical, but also socio-cultural elements such as the capability to take part in the life of society ("gewährleistet das Existenzminimum durch eine einheitliche grundrechtliche Garantie, die sowohl die physische Existenz des Menschen [...] als auch die Sicherung der Möglichkeit zur Pflege zwischenmenschlicher Beziehungen und zu einem Mlndestmaß an Teilhabe am gesellschaftlichen, kulturellen und politischen Leben umfasst, denn der Mensch exisitiert notwendig in sozialen Bezügen", BVerfGE 125175223.

${ }^{124}$ Sen 1983:161.

125 161-162.

${ }^{126}$ German Federal Constitutional Court (Bundesverfassungsgericht) BVerfGE 125175 223; "[The] nature of relative poverty extends even further, to the ways in which people are perceived by others in society", Fredman 2011:569.

${ }^{127}$ Fredman 2011:569.

128571.

${ }^{129} 571$.
} 
4112 The relation between poverty and equality ${ }^{130}$

The fact that goals of preferential procurement such as poverty-alleviation and equality need to be distinguished, does not contradict the finding that both these goals are intertwined. Only when both dimensions are distinguished in principle, commonalities and interdependencies can be discussed. The relationship between equality and poverty is a complicated one. ${ }^{131}$ It is ultimately not necessary - and arguably even impossible - to clearly separate poverty-related aspects from equality-oriented aspects. While poverty and inequality are not the same, they surely are deeply interlinked. ${ }^{132}$ It is however necessary to clearly distinguish between those aspects that refer to a more absolute understanding of poverty and those referring to a more relative understanding of poverty. The first category, or according to Sen the "irreducible absolutist core in the idea of poverty", 133 is more open to material aspects whereas the second category is more open to equality-oriented aspects.

This sets the framework for the further inquiry. In this part, the material aspects of poverty alleviation will be discussed. Firstly, it will be briefly outlined why the South African law of preferential procurement - in its current form - theoretically could be capable of addressing material aspects of poverty. Then it will be discussed whether such poverty-alleviation through preferential procurement is effective. The immaterial, relative, and more equalityoriented aspects of poverty will then be discussed in the following part labelled "Equalityoriented aspects". The interdependencies between poverty and equality as well as the fact that both aspects are deeply intertwined need to be acknowledged. Any too strict separation in terms of distinct goals would be merely artificial. At the same time, it is important to understand both poverty and equality as two separate aspects of one social problem. Thus for the remainder of the text I will refer to the more material and absolute aspects as poverty-alleviation and the more immaterial and relative aspects as equality.

\footnotetext{
${ }^{130}$ Inequality plays an important role in the measurement of poverty in the sense of the composition of 'the poor'. Given a specific poverty line the distance of an individual to that poverty line is crucial, Sen 1992:102. This aspect of inequality among the group of 'the poor' will not be dealt with in this text. It is however acknowledged that the composition of the group of people beneath the specified poverty line is crucial when measuring poverty and looking for effective policy instruments to alleviate poverty.

${ }^{131}$ Fredman 2011:567.

132 576-577. On the complicated relation see also van der Berg 2011.

${ }^{133}$ Sen 1983:159; Fredman 2011:571.
} 


\section{Poverty and race-based targeting}

The South African preferential procurement framework as contained in the PPPFA and the Preferential Procurement Regulations 2011 does not relate to socio-economic factors but only to B-BBEE status. ${ }^{134}$ Targeting based on race has been frequently criticised and it has been suggested to replace categories of race with categories of class or social status ${ }^{135}-$ at least with regard to instruments aiming at the alleviation of poverty. However statistics for the South African situation arguably suggest that this is a moot point insofar as the results would remain the same. Being poor in South Africa can still largely be equated with being black, i.e. a member of a certain race. While in 2008 79\% of black people were poor, this was only the case for $9 \%$ of coloured and white persons and $3 \%$ of Indian/Asian persons. ${ }^{136}$ Moreover, in $200893 \%$ of the poor population ${ }^{137}$ were black. ${ }^{138}$ Considering these statistics it does not seem unreasonable to address the problem of poverty by targeting a particular race.

\section{A pragmatic view on effectiveness: Econometric studies?}

The effectiveness of preferential procurement policies as instruments in the fight against poverty is mostly an economical, and to some extent sociological, issue. ${ }^{139}$

\section{Poverty-alleviation through affirmative action in general}

Especially with regard to BEE and B-BBEE policies, the alleviation of poverty by means of affirmative action measures has been brought up. It has been criticised that BEE "has achieved little success in eradicating poverty". ${ }^{140}$

Some empirical data for affirmative action measures in general and their effect on inequality and poverty is available. Katiyatiya elaborately analyses the impacts of affirmative action

\footnotetext{
${ }^{134}$ Bolton 2011:7.

${ }^{135}$ Katiyatiya 2014:199 et seq.

${ }^{136}$ Leibbrandt et al 2010:82 table A.3.11. The overall numbers are the same for both the lower poverty line of R515 per month and the upper poverty line of R949 per month. There however are differences in the rates among income quinitiles.

${ }^{137}$ Applying the lower poverty line of R515 per month.

${ }^{138}$ Leibbrandt et al 2010:37 table 2.11; see also Katiyatiya 2014:41.

${ }^{139}$ Quinot 2013:373.

140 Kovacevic 2007:6. Similarly Hamann et al 2008:25 who criticise progress of BEE in the fields of poverty, unemployment, housing and basic services, inequality and HIV/Aids.
} 
measures in the United States, Canada, and India. ${ }^{141}$ The conclusion for the United States is that -

\begin{abstract}
"[e]mpirical evidence indicates that the impact of affirmative action on poverty and inequality is minimal"; ${ }^{142}$ for Canada that "the impact of affirmative action policy on poverty and socio-economic inequality [...] has been minimal"; ${ }^{143}$ and for India that "[e]mpirical studies indicate that social discrimination [...] is still strong and pervasive" ${ }^{144}$ For the South African context it is - de lege lata - observed that "neither the issue of the current policy having contributed to the widening up of the poverty gap [in a shift from race- or gender based inequality to class-based inequality] nor the fact that the majority of the Africans are yet to reap the benefits from the redress strategy can be ignored". ${ }^{145}$ According to Katiyatiya, the empirical analysis "raises serious questions about the redistributive benefits of affirmative action measures". ${ }^{146}$
\end{abstract}

This analysis gives only little reason for hope for the case of affirmative action, especially with regard to poverty-alleviation.

\title{
4122 The case of preferential procurement
}

Trying to assess the economic effect of preferential procurement on poverty in South Africa is somewhat of an uphill battle. It is an economic issue and there are only few studies addressing the problem ${ }^{147}$ - one of the reasons for this dilemma likely being the lack of monitoring and general availability of data. ${ }^{148}$ It can however be attempted to draw from experiences with affirmative action in general and in other countries. When doing so, caution is necessary as results can vary significantly depending on the factual context. ${ }^{149}$

\footnotetext{
${ }^{141}$ Katiyatiya 2014:138 et seq.

142177.

143 177-178.

144178.

145207.

146234.

${ }^{147}$ Watermeyer 2000:230.

148 230; see Chatterji et al 2013:8 on the situation in the United States.

${ }^{149}$ Katiyatiya 2014:138.
} 


\section{The United States}

Katiytiya discusses the impact of preferential procurement in the United States. The United States also use preferential procurement. ${ }^{150}$ Besides other measures in public procurement such as requiring potential contractors to adhere to certain anti-discrimination rules, ${ }^{151}$ the United States' system prefers minority or disadvantaged groups in the procurement process by means of minority business enterprises programmes and small disadvantaged businesses programmes. ${ }^{152}$ Trying to assess the empirical impact of such affirmative action measures is critical. It is also very complicated. Within the empirical literature the purposes and goals of such programmes are hardly ever addressed ${ }^{153}$ and research on these topics is often incoherent and even contradictory. ${ }^{154}$ Nevertheless, it has been doubted that the US preferential procurement schemes reach their goals efficiently. ${ }^{155}$ The arguments are similar to the South African debate on BEE or B-BBEE as outlined above. It was argued that the programmes benefitted mostly those who were wealthy already. ${ }^{156}$ Furthermore, it was argued that those programmes do not reach their intended targets. ${ }^{157}$ Both programmes, those on minority-owned businesses and small disadvantaged businesses are said to exceed mere anti-discrimination purposes ${ }^{158}$ and "strengthen economic development and empowerment". ${ }^{159}$ This approach becomes especially apparent when considering the fact that the United States' system uses "[s]ocio-economic status as a criterion" 160 for preferential treatment. ${ }^{161}$ This way socio-economic goals, and arguably poverty alleviation, are incorporated into the procurement system. It thus can be argued that the United States' system of preferential procurement is even more designed towards fighting poverty. The

\footnotetext{
150142 , referring to "government contracting" as one of the three main branches of affirmative action in the United States; the others being education and employment; Sweet 2006:162.

${ }^{151}$ Katiyatiya 2014:144. This is a popular way to enforce labour standards through public procurement, see on this Watermeyer 2000:231 being critical on the efficiency of such instruments. Such an approach however has to be distinguished from preferential treatment for certain target groups.

152 Katiyatiya 2014:144-145, instruments such as "set-asides" and "sheltered markets" are used, 144; Sweet 2006:162.

${ }^{153}$ Sweet 2006:166-167; Katiyatiya 2014:146.

154 Sweet 2006:171-172.

${ }^{155}$ Katiyatiya 2014:147.

156147 n 689; Sowell 2004:121.

${ }^{157}$ Katiyatiya 2014:147.

158 149; Sweet 2006:161.

${ }^{159}$ Katiyatiya 2014:149.

160150.

161150.
} 
results however are still disappointing. Katiyatiya concludes that "[e]mpirical evidence indicates that the impact of affirmative action on poverty and inequality is minimal". ${ }^{162}$

It already has been stated that empirical findings on these impressions are rare. Sweet conducted a study on the United States' minority-owned businesses programme. ${ }^{163} \mathrm{He}$ assessed the construction industry in Philadelphia, Portland and Miami from 1981 to 2000. ${ }^{164}$ According to his findings, these programmes aimed, among others, at the redistribution of wealth. ${ }^{165}$ After simulating the impact of minority business enterprise programmes, Sweet concludes that those programmes in the United States, in their current form, do neither involve more minorities in construction nor "racial disparities". ${ }^{166}$ Even though Sweet acknowledges that there might be some (minimal) positive effects of minority business programmes, he advises to adopt another policy in order to achieve "substantial transformation of minority economic conditions". ${ }^{167}$

A more recent study on minority business programmes in the United States was conducted by Chatterji et al. in $2013 .{ }^{168}$ They too stipulate not only combating discriminatory practices against black business owners but also the redistribution of wealth as potential objectives of such programmes. ${ }^{169}$ In order to assess the impacts of the United States' set-asides programmes, Chatterji et al. constructed a new database. ${ }^{170}$ Their results differ from Sweet's. Chatterji et al. conclude that the United States' system of set-asides "had a large and significant impact on African-American business ownership during the 1980s, with the black-white self-employment gap falling by three percentage points. [...] The bettereducated were the primary beneficiaries [...]. Consistent with black-owned firms hiring a disproportionate number of blacks, the racial gap in employment fell roughly by four

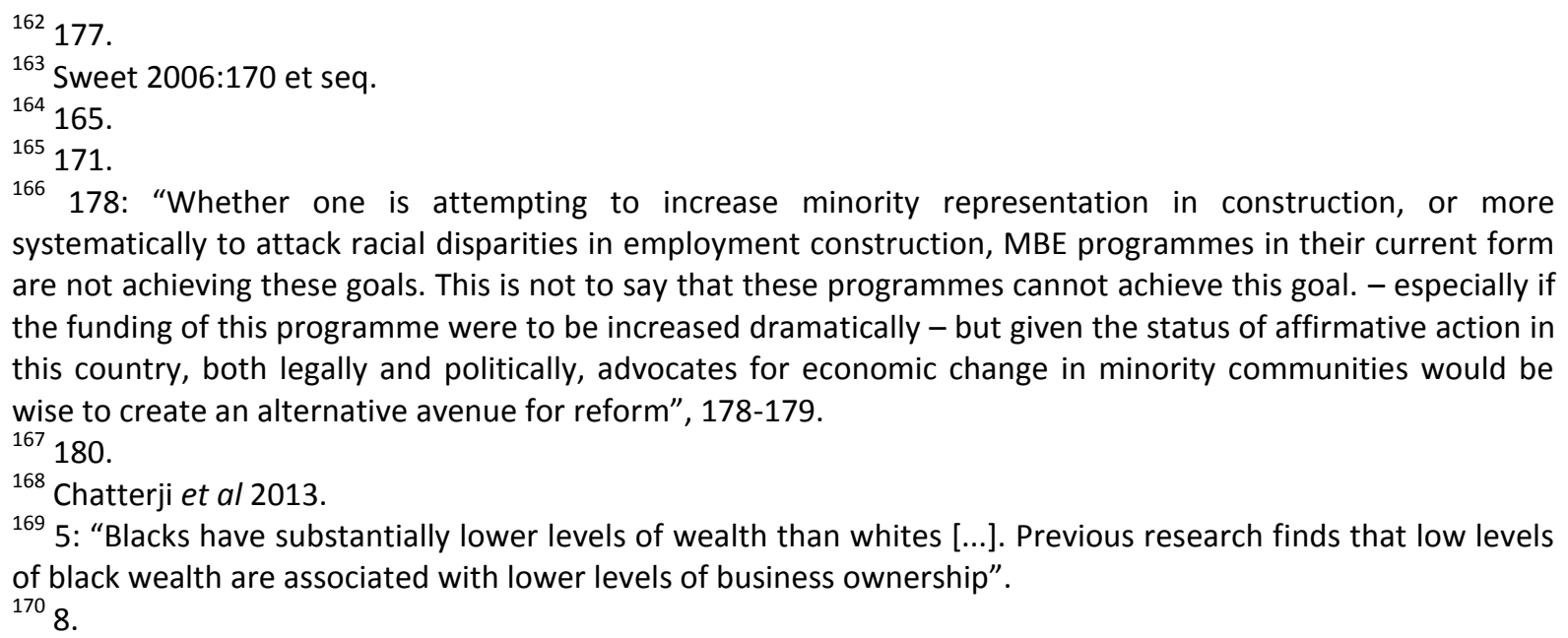
systematically to attack racial disparities in employment construction, MBE programmes in their current form are not achieving these goals. This is not to say that these programmes cannot achieve this goal. - especially if the funding of this programme were to be increased dramatically - but given the status of affirmative action in this country, both legally and politically, advocates for economic change in minority communities would be wise to create an alternative avenue for reform", 178-179.

167180.

168 Chatterji et al 2013.

169 5: "Blacks have substantially lower levels of wealth than whites [...]. Previous research finds that low levels of black wealth are associated with lower levels of business ownership". ${ }^{170} 8$. 
percentage points after set-asides". ${ }^{171}$ Despite the emphasis on some caution due to general economic influences, ${ }^{172}$ Chatterji et al. conclude that their "findings imply that government contracts can have real impacts on the number of business owners and employment" ${ }^{173}$

\section{South Africa}

In the South African context, few authors have written about the situation in the construction sector. In a recent study, Letchmiah investigates the impact of preferential procurement on opportunities for historically disadvantaged persons to take part in the economy. ${ }^{174}$ The results were promising. After evaluating National Treasury data, Letchmiah found that in the five-year period from $2006 / 2007$ to $2010 / 2011,{ }^{175} 84.6 \%$ of the contracts in numbers and $88.8 \%$ of the total value of contracts went to businesses with at least some share of historically disadvantaged persons. ${ }^{176} 72.2 \%$ of the contracts in numbers were awarded to businesses which were $100 \%$ owned by historically disadvantaged persons. ${ }^{177}$ $43.3 \%$ of the total value of government contracts in the five year period were awarded to businesses owned $100 \%$ by historically disadvantaged persons. ${ }^{178}$ Letchmiah therefore concludes that "the application of the PPPFA (2000) contributed to the increased participation of enterprises with HDI shareholding in terms of winning government construction contracts". ${ }^{179}$ Yet it is also noted that small and medium enterprises owned by historically disadvantaged persons had only "access to a very low value of the total construction contracts made available by national and provincial government departments". ${ }^{180}$ This problem is not further addressed by the 2011 procurement regulations. ${ }^{181}$ Even raising the threshold for the application of the 80/20 system from $\mathrm{R} 500$ 000 to R1 000000 does not significantly increase the contract value available to small and medium enterprises. ${ }^{182}$ Those enterprises typically benefit from the $80 / 20$ system, the value

\footnotetext{
17134.

17234.

173 35-36.

174 Letchmiah 2012:288.

175126.

176290.

177290.

178290.

179291.

180291.

181 298-299.

182 298-299.
} 
of contracts to which this system is applied however make up only $2.8 \%$ of the total value of contracts. ${ }^{183}$ This arguably leads to an exclusion of small and medium enterprises. ${ }^{184}$

Earlier on, Watermeyer wrote on the topic of preferential procurement in the construction industry. In 1993, the share of business owned by black South Africans was less than $0.5 \%{ }^{185}$ In 1995, after apartheid but before the preferential procurement policy was introduced, the share still amounted to only $2.5 \% .{ }^{186}$ After the implementation of the policy, the share jumped to $22.29 \%$ in $1996 .{ }^{187}$ Watermeyer furthermore refers to a project for the Malmesbury prison complex near Cape Town where local enterprises were targeted. ${ }^{188}$ This project in 1996 started targeted procurement in South Africa ${ }^{189}$ and according to Watermeyer - "proved to be more efficient at channelling money into communities than some focused poverty alleviation programmes in South Africa involving the construction of community buildings". 190

\section{Conclusion}

The conclusion is twofold: first, studies concerning the United States and South Africa bring up mixed results. While some studies suggest positive effects of preferential procurement policies on minority-owned business, others suggest no effect at all. Second, the studies do not explicitly investigate the effect of preferential procurement on poverty-alleviation.

It is not the purpose of this paper to take part in the economic discussion about effects of preferential procurement. In the light of the outlined studies, only a few remarks will be made. Studies such as the ones conducted by Chatterji et al. and Letchmiah find an impact of preferential procurement in the sense of raised shares of businesses owned by targeted groups. Unfortunately this does not hold much information on the composition of the group of successful tenderers. Even a large share of minority-owned businesses or businesses owned by disadvantaged groups could result from only a few large enterprises being

\footnotetext{
183301.

184301.

${ }^{185}$ Watermeyer 2000:242.

186242.

${ }^{187} 242$ table 7.

188243.

189243.

190243.
} 
successful and benefitting from preferential treatment. In fact, especially the findings of Letchmiah concerning the potential and likely exclusion of small and medium enterprises from valuable contracts point exactly to this scenario. Even if preferential treatment leads to larger shares of targeted groups, these findings indicate that this is only true for larger enterprises which grow more and more successful. This would mean that those in need are not - or only marginally - affected by preferential procurement. The findings by Chatterji et al., that preferential procurement in the United States benefitted primarily the bettereducated, supports this impression. All this leads to the conclusion that the effectiveness of preferential procurement in alleviating poverty, be it based on socio-economic factors as in the United States or - a fortiori - be it based on race as in South Africa, ${ }^{191}$ has to be doubted.

\section{Effectiveness of social grants in the fight against poverty}

While it is almost impossible to obtain data on the poverty-reducing effect of preferential procurement, data is available for the effectiveness of social welfare grants in alleviating poverty. ${ }^{192}$ South Africa has a system of "social assistance grants" ${ }^{193}$ which will be focussed on in this paragraph. The programme consists of "non-contributory and income-tested benefits provided by the state to vulnerable groups unable to provide for their own minimum needs [...]. Benefits are financed out of general tax revenues" ${ }^{194}$ Grants include disability grants, Child Support Grants and old age pensions ${ }^{195}$ - only the latter two being aimed specifically at poverty alleviation. ${ }^{196}$ In South Africa, ${ }^{197}$ these social assistance grants are the main instrument in the fight against poverty and spending on social welfare,

\footnotetext{
${ }^{191}$ This relates to general criticism on BEE or B-BBEE policies in South Africa. It is argued that "BEE is based on redistribution according to race rather than wealth or income", Kovacevic 2007:6. Such criticism aims at a supposed purpose of BEE for poverty-alleviation in comparing it to redistributive measures based on wealth and income. The problem becomes apparent: while it may be correct that to a quite large extent poor parts of society equal black or coloured people, i.e. the categories of race and poverty overlap, it is by no means necessary that this always is the case. Thus targeting a particular racial group in order to eradicate poverty is systematically problematic. Critical statements as the one cited above also show a potential alternative to BEE, i.e. race-based, measures. Usually, redistribution based on wealth or income is achieved by tax-financed welfare instruments. More on this below.

${ }^{192}$ Which is not surprising given the fact that social grants are the prime instrument in the fight against poverty.

${ }^{193}$ Leibbrandt et al 2010:47.

19447.

19553.

19666.

${ }^{197}$ And in most other countries which have a similar programme.
} 
including social assistance amounted to R101.4 billion, or $4.4 \%$ of the GDP, in $2008 / 2009 .{ }^{198}$ Social grants were benefitting 13.4 million people in April 2009. ${ }^{199}$

Leibbrandt et al. define two different poverty lines, the lower poverty line at R515/month and the upper poverty line at R949/month, ${ }^{200}$ and simulate the effect of the South African social grants, namely the Child Support Grants and the old age grants on poverty using data from 2008. ${ }^{201}$ Regarding the lower poverty line, they state a decrease from $53.9 \%$ of persons below the poverty line without the grants to $45.7 \%$ including the grants. ${ }^{202}$ Regarding the upper poverty line, they state a decrease in 2008 from $68.2 \%$ to $65.4 \%{ }^{203}$ Considering Sen's remarks on the importance of differentiation among the group of 'the poor', ${ }^{204}$ it is sensible to look at different income quintiles. In doing so, the povertyalleviating effect of social grants becomes even more apparent. Applying the lower poverty line of R515 per month, South African social grants in 2008 "lift[ed] even some of the very poorest households [...] out of poverty". ${ }^{205}$ Social grants reduced the rate of persons in poverty from $100 \%$ to $96.4 \%$ within the lowest income quintile. ${ }^{206}$ The strongest effect was reported in the third income quintile where grants were found to reduce the poverty rate from $69.6 \%$ to $42.1 \%{ }^{207}$ The study conducted by Leibbrandt et al. thus shows that social grants in South Africa "have a significant impact on poverty". 208

\footnotetext{
198 Leibbrandt et al 2010:53. In 2000/2001 only R30.1 billion, or $3.2 \%$ of the GDP) have been spent on social welfare.

199.

20017.

${ }^{201} 66$ et seq.

${ }^{202} 66$ table 3.12. The number of $45.7 \%$ considers all persons who are eligible to grant money, 66 . Considering only those who in fact benefited from grant money, the poverty rate after grants would be at $48.0 \%, 66$ table 3.12. While it is important to note that accessibility is crucial for social grants, the goal here is to discuss the potential poverty-alleviating effect of social grants. Therefore it is sensible to look at all potential beneficiaries.

${ }^{203}$ Leibbrandt et al 2010:66 table 3.12. Considering only those who in fact benefited from grant money, the rate after grants would be $66.5 \%, 66$ table 3.12 .

${ }^{204}$ See above.

${ }^{205}$ Leibbrandt et al 2010:67.

${ }^{206} 66$ table 3.12, again using all persons who are eligible to grants as a reference. Referring to only those who reported grant money income, the decrease was from $100 \%$ to $97 \%, 66$ table 3.12 .

Applying the upper poverty line, poverty decease was reported within the lowest income quintile from $100 \%$ to $99.5 \%, 66$ table 3.12, i.e. was significantly lower.

${ }^{207} 66$ table 3.12, again using all persons who are eligible to grants as a reference. Referring to only those who reported grant money income, the decrease was from $69.6 \%$ to $51.2 \%, 66$ table 3.12 . It is not surprising that the strongest effect could be observed within the third income quintile as this was the 'last' quintile to contain persons under the poverty line. Both the fourth and fifth quintile had, applying the lower poverty line, no poor persons, 66 table 3.12 .
} 
Yet, it is also important to note that practical feasibility, especially financial capability of state and society, is crucial to a policy. ${ }^{209}$ Accepting this means that it is not sufficient to prove that social welfare grants are more effective in fighting poverty. Social grants, as shown, require huge amounts of tax-based spending. In 2008/2009 public expenditure on social grants in South Africa amounted to R101.4 billion. ${ }^{210}$ The financial dilemma becomes even more apparent when taking into account that in $200630.4 \%$ of South African households reported social grants as their main source of income ${ }^{211}$ and $55.2 \%$ reported to obtain any income from grants. ${ }^{212}$ When there are simply not enough financial capabilities, i.e. sufficient taxes, in order to grant substantial social welfare aid in South Africa, such policy recommendations would be useless. Poverty alleviation through preferential procurement has to be seen in this context. Linking the large amount of procurement spending - which have to be spent anyway - to social goals is sensible and the notion is that social goals such as poverty-alleviation could be achieved more cheaply. The question which has to be asked in this context is whether money that is rare anyways, should be spent on the more effective policy instrument of social grants - considering the costs of preferential procurement. $^{213}$

\section{Equality-oriented aspects}

All the problems mentioned above combined with the general acknowledgment that affirmative action measures in general are not the main instrument for the redistribution of wealth, ${ }^{214}$ arguably lead to the conclusion that in terms of poverty-alleviation, preferential procurement is significantly less effective than tax-based social grants. The question arising is whether preferential procurement - contrary to the general South African perception should be abandoned. When trying to answer this question it is however important to acknowledge a second dimension of preferential procurement besides the alleviation of

\footnotetext{
Applying the upper poverty line, poverty decease was reported within the third income quintile from $100 \%$ to $97.4 \%$ and in the fourth income quintile, i.e. the 'last' quintile to contain technically poor persons, from 41.1. $\%$ to $31.4 . \%, 66$ table 3.12 .

20867.

${ }^{209}$ Sen 1992:108; and limited, especially in developing countries, Watermeyer 2000:229.

${ }^{210}$ Leibbrandt et al 2010:53.

${ }^{211} 62$ table 3.9.

${ }^{212} 62$ table 3.10.

${ }^{213}$ See on this 4123.

${ }^{214}$ Katiyatiya 2014:236.
} 
poverty: the equality-oriented dimension. The social problem - as described - contains not only material aspects. The immaterial aspects are deeply linked to the issue of equality. Preferential procurement addresses these equality-oriented aspects. ${ }^{215}$ Aside from more pragmatic considerations, such as the limited financial potential of tax-based redistribution in the South African economy, the equality-oriented perspective provides for a normative view. When assessing the feasibility of preferential procurement, both perspectives, the economically influenced pragmatic and the equality-oriented normative perspective, have to be taken into account. In this regard, it is to be assumed that mere negative antidiscrimination law does not suffice to eradicate inequalities. ${ }^{216}$ In South Africa this approach stands on relatively solid ground as both sections 9 (2) and 217 (2) of the South African Constitution provide for positive measures in promoting equality. ${ }^{217}$

\section{Equality in the South African Constitution}

Section 217 of the Constitution is the central provision concerning procurement. Section 217 (1) states, among others, that the procurement system must be fair and equitable. This way section 217 (1) already promotes procedural equality, i.e. everyone involved in the process needs to be treated equally. ${ }^{218}$ The South African Constitution takes this one significant step further. It entrenches the idea of substantive equality. ${ }^{219}$ This idea is reflected in section 217 (2) of the Constitution which allows for preferential treatment. The constitutional framework for preferential procurement as an equality-oriented policy however does not end at section 217. It is influenced by the general constitutional equality clause in section 9 and has to be seen in this bigger context of transformation. ${ }^{220}$ In this

\footnotetext{
${ }^{215}$ On the categorization of policy instruments from their target see Graser 2013. Within this framework of equality-oriented policies preferential procurement can be evaluated, Graser 2013:2. For the purpose of this paper it will however be sufficient to identify the specific equality-oriented purpose of preferential procurement. Further categorization will not be discussed.

${ }^{216}$ Similarly Fredman 2002:6 calling positive measures part of a "new or third phase of equality law"; on a behavioural-law perspective on the problem of negative anti-discrimination law see Graser \& Alfinito Viera 2012.

${ }^{217}$ The notion of a relatively solid ground is true for the principle of positive equality-oriented measures; see for example Dupper 2002:275. The exact application however is highly contested, as is shown by the critical reactions to the judgement of the Constitutional Court in South African Police Service $v$ Solidarity obo Barnard (CCT 01/14) [2014] ZACC 23 (2 September 2014). For an overview of the problems, though before the CC judgement, see for example McGregor 2013.

218 Penfold \& Reyburn 2014:25-9.

${ }^{219}$ Albertyn \& Goldblatt 2014: 35-13; Langa 2006:352.

${ }^{220}$ On the importance of transformation Langa 2006:351.
} 
context, the principle of equality plays an important role. ${ }^{221}$ While there is no commonly accepted definition of transformation, ${ }^{222}$ Langa points to the Epilogue of the interim Constitution which characterises the Constitution as ${ }^{223}$

"a historic bridge between the past of a deeply divided society characterised by strife, conflict, untold suffering and injustice, and a future founded on the recognition of human rights, democracy and peaceful co-existence and development opportunities for all South Africans, irrespective of colour, race, class, belief or sex".

Transformation thus describes a process of change driven by certain values. It is a "social and economic revolution". ${ }^{224}$ Preferential procurement has to be viewed in this broader picture. Furthermore it is important to note the different possible scopes of transformation. These will be briefly addressed below.

\section{Dimensions of equality}

Equality as a principle has several, often contradictory, dimensions. ${ }^{225}$ Thus promoting equality in one dimension can very well lead to more inequality in another dimension. ${ }^{226}$ This also means that when assessing whether a certain policy instrument is implemented to promote equality, the social context - or the specific dimension - in which equality should be achieved needs to be defined. ${ }^{227}$ Fredman identifies four goals of substantive equality:

"[f]irst, it aims to break the cycle of disadvantage associated with status or out- groups. This reflects the redistributive dimension of equality. Secondly, it aims to promote respect for dignity and worth, thereby redressing stigma, stereotyping, humiliation, and violence because of membership of an identity group. This reflects a recognition dimension. Thirdly, it should not exact conformity as a price of equality. Instead, it should accommodate difference and aim to achieve structural change. This captures the transformative

\footnotetext{
${ }^{221}$ Albertyn \& Goldblatt 2014: 35-1.

222 Langa 2006:351.

${ }^{223} 352$; Epilogue of the interim Constitution.

${ }^{224}$ Langa 2006:352.

225 Sen 1992:12 et seq.

${ }^{226} 16$.

$22712-13,16,88$.
} 
dimension. Finally, substantive equality should facilitate full participation in society, both socially and politically. This is the participative dimension."228

\section{Preferential procurement and substantive equality}

Building on this understanding of substantive equality, it can now be discussed if and how preferential procurement is capable of serving it.

\section{Redistributive dimension}

According to Sen's capabilities approach on poverty, ${ }^{229}$ it is crucial for persons to be in fact able to pursue their choices. ${ }^{230}$ Due to certain varying and different constraints, it is not sufficient to provide only for formal equality. ${ }^{231}$ Thus, the redistributive dimension of substantive equality seeks to "redress disadvantage by removing obstacles to genuine choice". 232

Preferential procurement addresses this dimension of equality. During apartheid, oppressed groups of society were denied from participation, both in general society and the economy. ${ }^{233}$ Contracts with the state were a privilege for large companies which were mostly owned by whites. ${ }^{234}$ This left black-owned businesses and black economic activity to marginalisation. ${ }^{235}$ Preferential procurement can provide historically disadvantaged persons the opportunities to follow their economic choices. After such deep inequalities during the apartheid system, providing for formally equal opportunities alone was not enough. Given the unequal status under the apartheid system which resulted in both social and economic inequalities, the idea of preferential procurement might promote substantive equality in the field of government contracts where a purely cost-oriented approach would prove insufficient.

\footnotetext{
${ }^{228}$ Fredman 2011:577.

${ }^{229}$ See 411.

${ }^{230}$ Fredman 2011:578.

231578.

232578.

${ }^{233}$ Anthony 2013:60; Patel \& Graham 2012:194.

${ }^{234}$ Bolton 2008:785.

${ }^{235}$ Anthony 2013:60.
} 


\section{Participative dimension}

Preferential procurement also addresses the participative dimension of substantive equality. This dimension addresses "the importance of community in the life of individuals". ${ }^{236}$ As has been described, historically disadvantaged persons were socially and economically excluded in the apartheid system. The participative dimension of substantive equality includes "participation in economically or socially valuable activities". 237

Preferential procurement addresses the issue of unequal opportunities to economic participation. ${ }^{238}$ This can be best understood when comparing preferential procurement to the alternative presented above - social grants. Social grants, in awarding benefits completely independent from achievement or even activity run the risk of leading to social and economic exclusion. ${ }^{239}$ In other words: Preferential procurement is more than an instrument to redistribute wealth in terms of financial gains. Significantly more than social grants, preferential procurement addresses the issue of equality of opportunity. ${ }^{240}$ Preferential procurement seeks to include groups of society that were - due to discriminatory practices - left at the margins of economy. It does so not primarily by directly awarding these marginalised groups financial benefits ${ }^{241}$ but by promoting equal economic opportunities. This way preferential procurement directly addresses - in Fredman's terminology - the "participative dimensions" ${ }^{242}$ of substantive equality. It is ultimately not important whether this is directly or indirectly seen as poverty-alleviation, or completely

\footnotetext{
${ }^{236}$ Fredman 2011:580.

237580.

238 Anthony 2013:60. This is similar to the approach adopted in the United States. There the preferential procurement - according to Katiyatiya - "is targeted at minorities, affirming their identity, to pave a way for them to participate in the USA's economic system (thereby increasing their full social participation)", Katiyatiya 2014:150. Two differences to the South African system however become apparent: first, South African preferential procurement is not targeted at a minority, but at a economically marginalised group. The rationale however is the same. Second, the US system, unlike the South African system uses socio-economic disadvantage as a criterion for preferential treatment, 150.

${ }^{239}$ This is a highly contested subject, especially when comparing social grants to other methods of income generation, most importantly those which generate income through work, such as minimum wages. Studies conducted in Germany suggest that under a certain amount of income, recipients perceive the source of the income, be it social grants or own work, not as important, see Lesch \& Bennett 2010:85. In general however, the source of income, especially its relation to achievement, affects the perception and social grants can lead to social exclusion, Liebig \& Schupp 2008:26.

${ }^{240}$ Watermeyer et al 1998:17; Anthony 2013:60. See also Fredman 2011:584 on the need to "challenge antipoverty measures which themselves reinforce status discrimination".

${ }^{241}$ As social grants do.

${ }^{242}$ Fredman 2011:577. The United States' system takes a similar approach and seeks to remove "barriers to economic opportunities", Katiyatiya 2014:141.
} 
distinct from it. It is however crucial to acknowledge the different approach preferential procurement takes compared to social grants. Preferential procurement addresses a dimension of equality, or an equality-oriented aspect of poverty, that social grants are incapable of. ${ }^{243}$

If we seek to justify preferential procurement - despite rather apparent problems with its economic effectiveness and efficiency - we cannot simply argue that preferential procurement promotes equality. It does, but so does the 'main contender' social grants; both of them in different dimensions, of course. While preferential procurement promotes inclusion, social grants promote equality of income. ${ }^{244}$ Justification of preferential procurement does not necessarily boil down to weighing and balancing these two dimensions against each other, the clear distinction however is necessary. ${ }^{245}$ When trying to justify preferential procurement in a normative dimension, we must thus refer to the importance of social inclusion.

\section{Difficulties}

Referring to the equality-oriented dimension of preferential procurement of course is not the 'holy grail' in the discussion surrounding preferential procurement. Horizontal policies in procurement which are understood as instruments to alleviate poverty suffer from the problems as described above - preferential procurement to promote substantive equality also has to be viewed cautiously. In this context it can be referred to the general discussion surrounding BEE or B-BBEE measures in South Africa.

\section{The broader context: Black Economic Empowerment in South Africa}

Preferential procurement is part of the Black Economic Empowerment policy (BEE). ${ }^{246}$ Within the transformation of South-Africa's post-apartheid society, black economic

\footnotetext{
${ }^{243}$ Of course preferential procurement - compared to welfare grants - is not the only instrument capable of providing equality. In fact, social welfare grants as arguably the main instrument of wealth-redistribution are the traditional instruments to promote equality. It does however contribute to a different dimension of equality than preferential procurement with its aspect of social and economic inclusion.

${ }^{244}$ Leibbrandt et al 2010:67.

${ }^{245}$ See Sen 1992:95.

${ }^{246}$ Sekgaphane 2009:5; Bolton \& Quinot 2011:275.
} 
empowerment - as a policy instrument - plays an important role. ${ }^{247}$ The issue has been discussed and criticised rather vividly. For the purpose of this text, one of the major aspects of criticism will be focused on. After having firstly been installed as "Black Economic Empowerment" (BEE), the policy has then quickly been reformed to "Broad Based Black Economic Empowerment" (B-BBEE) which reflects one of the major points of criticism. As very often with affirmative action measures, B-BBEE has to deal with the accusation of producing only an elite of beneficiaries while the, more broad, problems are not tackled - or not tackled sufficiently. As will be shown, this line of criticism is particularly relevant to the procurement-related aspects of B-BBEE.

\section{Purposes of BEE and B-BBEE}

The B-BBEE Act $^{248}$ defines its objectives as $-{ }^{249}$

“(a) promoting economic transformation in order to enable meaningful participation of black people in the economy;

(b) achieving a substantial change in the racial composition of ownership and management structures and in the skilled occupations of existing and new enterprises;

(c) increasing the extent to which communities, workers, cooperatives and other collective enterprises own and manage existing and new enterprises and increasing their access to economic activities, infrastructure and skills training;

(d) increasing the extent to which black women own and manage existing and new enterprises, and increasing their access to economic activities, infrastructure and skills training;

(e) promoting investment programmes that lead to broad-based and meaningful participation in the economy by black people in order to achieve sustainable development and general prosperity;

\footnotetext{
${ }^{247}$ Sekgaphane 2009:3; Krüger 2011:209 citing an old statement of the Department of Trade and Industry. A statement with similar content can now be found, describing the objective of B-BBEE as "to advance economic transformation and enhance the economic participation of black people in the South African economy", Department of Trade and Industry. Broad-Based Black Economic Empowerment. [online] Available at: <https://www.thedti.gov.za/economic_empowerment/bee.jsp> [Accessed 13 January 2015].

${ }^{248}$ No. 53 of 2003.

${ }^{249}$ S 2.
} 
(f) empowering rural and local communities by enabling access to economic activities, land, infrastructure, ownership and skills; and

(g) promoting access to finance for black economic empowerment."

According to other voices, BEE is "the South African government's policy instrument intended to redress inequalities of the past, eradicate poverty ${ }^{250}$ and to encourage equality and black participation in the formal economy" ${ }^{251}$ B-BBEE then, according to Sekgaphane, was, amongst others, "an attempt to narrow the poverty gap between rich and poor". ${ }^{252}$

\section{Criticism}

There is only little research on the impact of B-BBEE policies. ${ }^{253}$ It is often alleged that BEE only leads to a relatively small black elite ${ }^{254}$ whereas the broader problems are not sufficiently tackled. ${ }^{255}$ This is closely related to the purpose of BEE and B-BBEE policies to promote equality. It is alleged that BEE policies lead to "the perpetuation of a small black elite [...] without aiding the masses who are most in need". ${ }^{256}$ B-BBEE still benefits mostly already well established stakeholders such as "individuals who were well connected politically and in the business community". ${ }^{257}$ Broad-based partners, such as NGO's which represent broader groups, benefitted only in $7.6 \%$ of B-BBEE deals in 2004, of $6.4 \%$ in 2005 and of $14 \%$ in $2006 .{ }^{258}$ Despite the increase, B-BBEE still struggles to reach marginalised groups. ${ }^{259}$ Kovacevic further provides an example where in 2003 sixty percent of empowerment deals, or R25.3 billion benefitted only two companies. ${ }^{260}$ This issue has

\footnotetext{
${ }^{250}$ My highlight.

${ }^{251}$ Sekgaphane 2009:3.

2525.

253 Patel \& Graham 2012:193.

254 The phrase "Black Diamonds" is common. It is however somewhat problematic because of its reference to race, Chevalier 2011:9. It is also not popular among the black middle class, 9. Descriptive on the criticism on BBBEE only benefitting elites Patel \& Graham 2012:193.

${ }^{255}$ Kovacevic 2007:6.

${ }^{256} 6$.

257 Patel \& Graham 2012:201.

258 201-202 figure 2.

259201.

${ }^{260}$ Kovacevic 2007:6. Another approach mentioned by Katiytiya is the one of 'creamy layers' as used in India, Katiyatiya 2014:175, 241. The idea is to ensure that privileged parts of designated groups are not eligible for preferential treatment, 175 . This could address the problem of elitism caused by affirmative action. Elitebuilding through affirmative action is a major concern. Applied to preferential procurement, the elite-building in fact is inherent in the procurement system and -to some extent - desired. As long as public procurement
} 
moreover already been mentioned with regard to the effectiveness of preferential procurement policy in the fight against poverty. It has been seen that the vast majority of total contract value is awarded to larger enterprises with small and medium businesses at the brink of exclusion.

\section{Preferential procurement: desired elite-building?}

This line of criticism, that affirmative action measures do not reach those who need it the most, can be applied to preferential procurement. An important factor for the choice of the successful tenderer is their "capability/ability [...] to execute the contract" ${ }^{261}$ According to Bolton, "relevant factors [to determine the capability/ability] include financial and economic standing; experience and track record; and the nature, quality, and reliability of products or services to be rendered". ${ }^{262}$ More factors "that would generally play a role in the determination of qualification or responsibility" 263 are "the nature, quality and reliability of the product or service to be rendered; the experience and track record of a contractor; the possession of appropriate licenses and permits; the ability of a contractor to comply with the delivery schedule; the contractor's record of business ethics and integrity; the technical knowledge and capacity of a contractor; the availability of tools or equipment for the contractor's use; and the financial and economic standing of a contractor". ${ }^{264}$ All these criteria favour established and proven tenderers. As far as 'negative' criteria are concerned, it is important to notice that contractors may be excluded if they failed to satisfactorily provide goods or services in an earlier contract. ${ }^{265}$ The - correct - assumption is that failure

heavily relies on cost-effectiveness as its main purpose and, linked to that, the qualification of a tenderer as the main award criterion, 'creamy layers' are entirely foreign to the procurement system; see on this 52.

${ }^{261}$ National Treasury of the Republic of South Africa, 2004. Implementation of Supply Chain Management. [online] Available at: <http://www.treasury.gov.za/legislation/pfma/circulars/Circular\%20\%20Implementation\%20of\%20Supply\%20Chain\%20Management.pdf> [Accessed 13 January 2015]: s 4.1 (b); Bolton 2008:790.

262 Bolton 2008:790.

263791.

264791.

265 National Treasury of the Republic of South Africa, 2005. Regulations for Departments, Trading Entities, Constitutional Institutions and Public Entities. GG227388 of 15 March 2005. [online] Available at: <http://www.treasury.gov.za/legislation/pfma/regulations/gazette_27388.pdf> [Accessed 13 January 2015]:s 16.A9.2 (a) (iii); National Treasury of the Republic of South Africa, 2005. Municipal Supply Chain Management Regulations. General Notice 868 of 2005, 30 May 2005. [online] Available at: <http://mfma.treasury.gov.za/MFMA/Regulations\%20and\%20Gazettes/Municipal\%20Supply\%20Chain\%20Ma nagement\%20Regulations\%20-\%20Gazette\%20No\%2027636,\%2030\%20May\%202005.pdf> [Accessed 13 January 2015]:s 38 (1) (d) (ii); Bolton 2008:791. 
to satisfactorily render services in an earlier contract will likely lead to unsatisfactory outcomes in another, new contract. ${ }^{266}$ E contrario this means that good experiences with a particular contractor in earlier contracts justify the assumption that this contractor will again render services satisfactorily, thus - legitimately enhancing this contractor's capability/ability in terms of the Treasury Guidelines. ${ }^{267}$ A contractor who already worked well on an earlier contract will thus be more likely - given otherwise similar circumstances to be awarded a contract.

This is in line with the goal of public procurement being cost-effective, i.e. value for money. The importance of 'traditional' award criteria is also reflected in the PPPFA. Of 100 points in total, 80 or 90 are awarded on the basis of price. ${ }^{268}$ Price - and with it the principle of costeffectiveness - thus is, even in the light of section 217 (2) of the Constitution still the dominant criterion. ${ }^{269}$ However, recapitulating on the criticism on BEE (or B-BBEE) policies to only benefit a relatively small elite among designated groups, this criticism becomes especially relevant in the procurement context. Given the dominance of cost-effectiveness, the 'natural enemy' of affirmative action measures, elite-building among the marginalised group, supports the main purpose of public procurement. ${ }^{270}$

\section{The function of preferential procurement in South Africa}

Preferential procurement policies promote various objectives. The two which are arguably most important are reducing inequalities and alleviating poverty. Being affirmative action measures, the main objectives of preferential procurement policies should be to promote equality, especially equality of opportunities understood in a participative way. It is crucial to be aware of this primary function. It however cannot be denied that preferential procurement policies are also seen as an instrument in the fight against poverty - not only in South Africa but also for example in the United States. If we were to reduce the objectives

\footnotetext{
266 Bolton 2008:792.

${ }^{267}$ National Treasury of the Republic of South Africa, 2004. Implementation of Supply Chain Management:4.1. (b).

${ }^{268}$ See 322.

${ }^{269}$ Penfold \& Reyburn 2014:25-1.

${ }^{270}$ In this regard it has to be noted that contradicting goals in public procurement are common, Kattel \& Lember 2010:383. However, in the case of preferential procurement as a means to promote substantive equality, the main purpose of procurement, cost-effectiveness, reinforces the common criticism of affirmative action as benefitting only a small elite. This leads to the question whether preferential procurement is, systemically, the appropriate instrument to promote substantive equality in this sense.
} 
of preferential procurement policies on their effect on poverty, we would most likely have to argue to abolish the policies in favour of broader and more effective social grants. Then the costs-affiliated with preferential procurement would be better used financing social grants.

Especially $^{271}$ in South Africa preferential procurement however needs to serve the purpose of promoting substantive equality. Transformation of society also calls for participative equality of formerly economically marginalised groups. It is not sufficient to try to achieve transformation only in the broader scope through welfare grants. It is acknowledged that preferential procurement in this regard is also problematic, as due to its main objective of cost-effectiveness suffers to an even larger degree from the criticism of leading to elites. It does however, as the study by Letchmiah has shown, lead to more participation of business owned by historically disadvantaged persons in general. Understood this way, preferential procurement can be a legitimate policy in South Africa. The necessity of both other, more broad-based equality-oriented measures and especially social grants to alleviate poverty however shifts the focus on the costs side of preferential procurement policies. Within the transformative policy system in South Africa, preferential procurement has its place. Not to alleviate poverty, but to provide substantive participative equality.

\section{Costs of preferential procurement}

The need of additional social grants however calls for a cautious monitoring of costs of preferential procurement. The following paragraphs will not seek to present a solution to this problem but only make a few remarks on the significance of costs.

"Even where benefits can be achieved, these must be weighed against the cost of doing so through procurement, either in terms of a price premium or a compromise on other matters such as time or quality". ${ }^{272}$ Preferential procurement, while an intriguing instrument in countries with little financial capabilities, still comes with costs. According to Watermeyer's statement cited above, these costs are mainly constituted by either a "price premium", i.e. higher prices of tenders or lower quality of service delivery. In general it can be assumed

\footnotetext{
${ }^{271}$ But certainly not exclusively.

${ }^{272}$ Watermeyer 2003:13.
} 
that fewer tenderers due to less competition lead to higher prices. ${ }^{273}$ This however is not cast in stone as, depending on the implementation, horizontal policies may in fact decrease the price. $^{274}$

According to the scope of this text, a study assessing the costs of the South African system of preferential procurement de lege lata will briefly be outlined. ${ }^{275}$ In analysing Treasury data for the five-year period from 2006/2007 to 2010/2011, Letchmiah finds only "unexpectedly low" price premiums. ${ }^{276}$ Only $5.8 \%$ of combined national and provincial contracts were awarded with a price premium and the average "percentage premium value was $1.4 \% " .{ }^{277}$ According to Letchmiah, "preferential procurement [as applied in South Africa] ${ }^{278}$ did not result in excessively high cost premiums for governments". ${ }^{279}$ This means that tenders issued by members of targeted groups were generally competitively priced. ${ }^{280}$ Furthermore, even if price premiums had to be paid, these came with a benefit. Such increased prices should be regarded as costs for the promotion of social goals ${ }^{281}$ which the state is obliged to promote anyways.

\section{Conclusion}

The look at the South African system of preferential procurement has shown a strong acceptance for the principle. Given the fact that one of the main purposes is to address past discrimination, this degree of acceptance is hardly surprising. Furthermore, even in the traditionally sceptical European procurement system the acceptance for horizontal policies is on the rise. This indicates that the discussion should no longer be about whether horizontal policies in principle are a viable instrument but more which particular policy for which particular purpose should be implemented. South African procurement law uses

\footnotetext{
${ }^{273}$ Quinot 2013:377.

274 377-378, referring for example to increased competition in the long run due to better access to the market for more tenderers, 378.

275 It has to be noted that it is important to take the issue of costs into account when thinking about procurement alternatives de lege ferenda.

276 Letchmiah 2012:279.

277278 table 6.13.

${ }^{278}$ Instruments to implement social policies in public procurement can be divided into price preferences, setasides, step-in mechanisms and fixed contract participation goals, Watermeyer 2000:230. Here the focus will however only be the current implementation in South Africa.

279 Letchmiah 2012:281.

280292.

281292.
} 
preferential procurement in order to reduce inequalities and alleviate poverty. The first initial proposition was that these two issues constituted two distinctly different goals. This proposition held only partially true. Poverty and equality are co-dependent and deeply interlinked. Any too strict separation therefore would be artificial. It however has to be acknowledged that, while they both concern the same social problem, they are two different aspects of this problem. Thus some differentiation is necessary and possible.

With regard to the second proposition the effectiveness of preferential procurement in South Africa, de lege lata, is hard to evaluate. This is mostly due to a lack of dedicated empirical research on the impact of preferential procurement on poverty. In citing some studies dealing with affirmative action in general and the impact of preferential procurement on targeted businesses it however can be concluded that there remain doubts about the plausibility of the use of preferential procurement in the fight against poverty. In this regard it is highly likely that social grants prove to be the more effective measure.

The comparison with social grants however points to another purpose of preferential procurement - the promotion of substantive equality in the form of participative equality. ${ }^{282}$ Transformation undoubtedly is both an important process as well as an important goal in South Africa. The issue of preferential procurement raises the question of the correct scope of transformation. Should we look at distinct fields such as the economy or even more narrow: specific types of economy? Or is transformation to be a broader concept, affecting the society as a whole? Narrow transformation by means of preferential procurement can address the aspect of social and economic inclusion which is inherent in substantive equality as contained in section 9 of the Constitution. Broader transformation in the sense of an effective fight against poverty could likely be better achieved by strengthening social grants. Ultimately it comes down to defining the desired outcome of the transformational process. Not least the constitutional equality clause points to a society in which social and economic participation are crucial. Preferential procurement can despite all the problems such as elite-building - serve this purpose. Preferential procurement has shown to significantly involve formerly marginalised businesses. Its likely ineffectiveness in the fight against poverty needs to be addressed by additional social

${ }^{282}$ And to some extent redistributive equality. 
grants. Therefore the costs of preferential procurement have to be assessed carefully. A study assessing the costs of the current South African system does however suggest that preferential procurement as it is implemented now is not overly costly.

\section{Bibliography}

\section{Books}

Albertyn, C. \& Goldblatt, B. 2014. Equality. In Woolman, S. \& Bishop, M. (Eds.). Constitutional Law of South Africa. 2nd ed. Cape Town: Juta.

Basheka, B. 2009. Public Procurement Reforms in Africa. In Thai, K.V. (Ed.). International Handbook of Public Procurement. Boca Raton: Taylor \& Francis Group.

Bolton, P. 2007. The law of government procurement in South Africa. Durban: LexisNexis.

Bolton, P. \& Quinot, G. 2011. Social policies in procurement and the Agreement on Government Procurement. In Arrowsmith, S. \& Anderson, R.D. (Eds.). The WTO regime on government procurement. Cambridge: Cambridge University Press.

Brammer, S. \& Walker, H. 2007. Sustainable procurement practice in the public sector. University of Bath.

Fredman, S. 2002. Discrimination Law. Oxford: Oxford University Press.

Hjelmborg, S.E., Jakobsen, P.S. \& Poulsen, S.T. 2006. Public Procurement Law. Copenhagen: Djoef.

Lesch, H. \& Bennett, J. 2010. Arbeit und Fairness. Köln: Institut der deutschen Wirtschaft.

McCrudden, C. 2007. Buying Social Justice. Oxford: Oxford University Press.

McCrudden, C. 2009. Social Policy Choices and the International and National Law of Government Procurement. In Corder, H. \& Glazewski, J. (Eds.). Global Administrative Law. Cape Town: Juta. 
Mille, A. 2006. Collateral Objectives in Public Procurement. In Gruber, G., Gruber, T., Mille, A. \& Sachs, M. (Eds.). Public Procurement in the European Union. Vienna, Graz: Neuer Wissenschaftlicher Verlag.

Mokakala, L. L. 2010. The viability of preferential procurement in the metals and engineering sector. North-West University.

Penfold, G. \& Reyburn, P. 2014. Public Procurement. In Woolman, S. \& Bishop, M. (Eds.). Constitutional Law of South Africa. 2nd ed. Cape Town: Juta.

Quinot, G. 2013. Promotion of social policy through public procurement in Africa. In Quinot G. \& Arrowsmith, S. (Eds.). Public Procurement Regulation in Africa. Cambridge: Cambridge University Press.

Sen, A. 1992. Inequality reexamined. Oxford: Oxford University Press.

Sowell, T. 2004. Affirmative Action around the World. New Haven: Yale University Press.

\section{Theses}

Anthony, A.M. 2013. The Legal Regulation of Construction Procurement in South Africa. LL.M. Stellenbosch University.

Katiyatiya, L.M. 2014. Substantive Equality, Affirmative Action and the Alleviation of Poverty in South Africa. LL.D. Stellenbosch University.

Le Roux de la Harpe, S.P. 2009. Public Procurement Law: A Comparative Analysis. LL.D. University of South Africa.

Letchmiah, D.R. 2012. An Examination of the Effectiveness of Preferential Procurement in the South African Construction Industry. DPhil. University of Witwatersrand.

Sekgaphane, L.P. 2009. Barriers to the Creation of Entrepreneurs Through Black Economic Empowerment. Magister Commercii. University of Johannesburg. 


\section{Journal articles}

Ambe, I.M. \& Badenhorst-Weiss, J.A. 2012. Procurement Challenges in the South African Public Sector. Journal of Transport and Supply Chain Management 6:242-261.

Arrowsmith, S. 2010. Horizontal Policies in Public Procurement. Journal of Public Procurement 10:149-186.

Bolton, P. 2006. Government Procurement as a Policy Tool in South Africa. Journal of Public Procurement 6:193-217.

Bolton, P. 2008. The Public Procurement System in South Africa. Public Contract Law Journal $37: 781-802$.

Bolton, P. 2011. New Preferential Procurement Regulations Released. Local Government Bulletin 13:7.

Dupper, O. 2002. Affirmative Action and Substantive Equality. South African Mercantile Law Journal 14:275-292.

Foster, J.E. 1998. Absolute versus Relative Poverty. The American Economic Review 88:335341.

Fredman, S. 2011. The potential and limits of an equal rights paradigm in addressing poverty. Stellenbosch Law Review 22:566-590.

Fuchs, C. 2012. Vergaberecht als Instrument. Journal für Rechtspolitik 20:288-297.

Furneaux, C. \& Barraket, J. 2014. Purchasing social good(s): a definition and typology of social procurement. Public Money \& Management 34:265-272.

Hamann, R., Khagram, S. \& Rohan, S. 2008. South Africa's Charter Approach to PostApartheid Economic Transformation. Journal of Southern African Studies 34:21-37. 
Kattel, R. \& Lember, V. 2010. Public procurement as an industrial policy tool. Journal of Public Procurement 10:368-404.

Kovacevic, N. 2007. Righting Wrongs. Harvard International Review 29:6.

Krüger, L.P. 2011. The impact of black economic empowerment (BEE) on South African businesses. Southern African Business Review 15:201-233.

Langa, P. 2006. Transformative Constitutionalism. Stellenbosch Law Review 17:351-360.

Liebig, S. \& Schupp, J. 2008. Leistungs- oder Bedarfsgerechtigkeit. Soziale Welt 59:7-30.

Lukosiuniene, R. \& Lukosiunas, L. 2014, Social Aspects of the Reform to the European Union Public Procurement Law. Social Transformations in Contemporary Society:173-182.

Madden, D. 2000. Relative or Absolute Poverty Lines. Review of Income and Wealth 46:181199.

McGregor, M. 2013. Affirmative action on trial. Tydskrif vir die Suid-Afrikaanse Reg: 650-675.

Patel, L. \& Graham L. 2012. How broad-based is broad-based black economic empowerment? Development Southern Africa 29:193-207.

Sahle, D. 2002. Procurement - A tool to address key development and social issues. ASIST Bulletin 14:1,4-5.

Sen, A. 1983. Poor, relatively speaking. Oxford Economic Papers 35:153-169.

Sweet, M. 2006. Minority Business Enterprise Programmes in the United States of America. Journal of Law and Society 33:160-180.

van der Berg, S. 2011. Current Poverty and Income Distribution in South Africa. Economic History of Developing Regions 26:120-140.

Watermeyer, R. 2000. The use of Targeted Procurement as an Instrument of Poverty Alleviation and Job Creation in Infrastructure Projects. Public Procurement Law Review $5: 226-250$ 
Watermeyer, R. 2003. Implementing preferential procurement policies in the public sector in South Africa. Journal of the South African Institution of Civil Engineering 45:11-22.

Watermeyer, R., Gounden, S., Letchmiah, D. \& Shezi, S. 1998. Targeted procurement. Journal of the South African Institution of Civil Engineering 40:15-25.

Westermann, H.P. 2008. Drittinteressen und öffentliches Wohl. Archiv für die civilistische Praxis:141-181.

Zacher, H.F. 2008. Die Entwicklungsländer-Forschung in den ersten Jahrzehnten des MaxPlanck-Instituts für ausländisches und internationales Sozialrecht. Zeitschrift für ausländisches und internationales Arbeits- und Sozialrecht 22:1-38.

\section{Papers}

Chatterji, A.K., Chay, K.Y. \& Fairlie, R.W. 2013. The Impact of City Contracting Set-Asides on Black Self-Employment and Employment. [pdf] Discussion Paper Series. Forschungsinstitut zur Zukunft der Arbeit. No. 7298. Available at:

<http://www.econstor.eu/bitstream/10419/71676/1/741295113.pdf> [Accessed 23 March 2015].

Chevalier, S. 2011. The Black Diamonds: a South African phantasmagoria. [doc] Available at: <http://www.Ise.ac.uk/anthropology/research/popular_economies/35b_Sophie_Chevalier. doc> [Accessed 23 March 2015].

Graser, A. 2013. Equality-oriented policies. [pdf] Available at:

<http://papers.ssrn.com/sol3/papers.cfm?abstract_id=2220289> [Accessed 23 March 2015].

Graser, A. \& Alfinito Viera, A.C. 2012. Taming the Biased Black Box? On the Potential Role of Behavioral Realism in Anti-Discrimination Policy. [pdf] Available at: <http://papers.ssrn.com/sol3/papers.cfm?abstract_id=2209999> [Accessed 24 March 2015]. 
Leibbrandt, M., Woolard, I., Finn, A. \& Argent, J. 2010. Trends in South African Income Distribution and Poverty since the Fall of Apartheid. OECD Social, Employment and Migration Working Papers No. 101. [pdf] Available at: <http://www.oecdilibrary.org/content/workingpaper/5kmms0t7p1msen?crawler=true\&mimetype=application/pdf> [Accessed 24 March 2015].

Semple, A. 2012. Refom of the EU Procurement Directives and WTO GPA. [pdf] Available at: <http://papers.ssrn.com/sol3/papers.cfm?abstract_id=2089357> [Accessed 24 March 2015].

\section{Internet sources}

Department of Trade and Industry. Broad-Based Black Economic Empowerment. [online] Available at: <https://www.thedti.gov.za/economic_empowerment/bee.jsp> [Accessed 13 January 2015].

National Treasury of the Republic of South Africa. General Procurement Guidelines. [online] Available at:

<http://www.treasury.gov.za/legislation/pfma/supplychain/General\%20Procurement\%20G uidelines.pdf> [Accessed 13 January 2015].

National Treasury of the Republic of South Africa, 2004. Implementation of Supply Chain Management. [online] Available at:

<http://www.treasury.gov.za/legislation/pfma/circulars/Circular\%20\%20Implementation\%20of\%20Supply\%20Chain\%20Management.pdf> [Accessed 13 January 2015]

National Treasury of the Republic of South Africa, 2005. Municipal Supply Chain Management Regulations. General Notice 868 of 2005, 30 May 2005. [online] Available at: <http://mfma.treasury.gov.za/MFMA/Regulations\%20and\%20Gazettes/Municipal\%20Suppl y\%20Chain\%20Management\%20Regulations\%20\%20Gazette\%20No\%2027636,\%2030\%20May\%202005.pdf> [Accessed 13 January 2015]. 
National Treasury of the Republic of South Africa, 2005. Regulations for Departments,

Trading Entities, Constitutional Institutions and Public Entities. GG227388 of 15 March 2005.

[online] Available at:

<http://www.treasury.gov.za/legislation/pfma/regulations/gazette_27388.pdf> [Accessed 13 January 2015].

World Bank, 2013. South Africa. [online] Available at:

<http://data.worldbank.org/country/south-africa> [Accessed: 23 March 2015].

\section{Cases}

\section{European Union}

ECJ C-513/99 [2002] ECR I-07213 Concordia

\section{South African}

Cash Paymaster Services (Pty) Ltd vs The Province of the Eastern Cape [1997] 4 All SA 363 (Ck)

South African Police Service v Solidarity obo Barnard (CCT 01/14) [2014] ZACC 23 (2 September 2014)

\section{German}

German Federal Constitutional Court (Bundesverfassungsgericht) BVerfGE 125175. 